\title{
The Navy and Canada's National Interests in this Maritime Century $^{1}$
}

\section{Vice-Admiral Dean McFadden}

Cet article présente la vision du chef d'état-major de la Force maritime à l'époque du centenaire, pour le rôle de la Marine canadienne à l'entrée du "siècle maritime ». Les océans seront d'une importance croissante pour la sécurité et la prospérité du Canada, et la défense du système mondial qui repose sur la liberté des mers est un aspect fondamental de la politique de défense du Canada, tout comme l'est la capacité de défendre depuis la mer les conditions qui assurent la prospérité du système mondial. Après avoir examiné ce que les défis seront susceptibles d'être, l'article explore comment les forces maritimes et navales du Canada contribueront à leur résolution.

\section{Introduction}

In this centenary of naval service to Canada, I have had numerous occasions to look back and reflect on the tremendous accomplishments of generations of sailors and maritime aviators, in both peace and war, which helped Canada to secure its place in today's world. However, in this article I will offer my reflections on the future. While no one can predict exactly what will happen in the decades ahead, I am confident in stating two things about the twenty-first century. First, the oceans will be of increasing importance to Canada's security and prosperity. Second, virtually every defence and security challenge I can envisage will require that Canada integrate all of the elements of the Canadian Forces - in fact, the entire arsenal of skills and competencies that this country has at its disposal - if it is to succeed.

The aim of this article is not to focus on how the Canadian Forces must organize to meet challenges, but rather what these challenges are likely to be, and why they should matter to Canadians. I will argue, as you might expect, that Canada's maritime air and naval forces will make a substantial contribution to addressing these challenges, as they did in the past 100 years and as they do today. But first, let me explain why the twentyfirst century will be a maritime century.

1 A slightly different version of this article first appeared in The Canadian Military Journal 10:4 (Autumn 2010), 53-58, available at: http://www.journal.forces.gc.ca/vol10/no4/doc/09mcfadden-eng.pdf (accessed 1 November 2010).

The Northern Mariner/Le marin du nord XXIV, Nos. 3 \& 4 (Jul. \& Oct. 2014), 349-356 Canadian Military History 23, Nos. 3 \& 4 (Summer \& Autumn 2014), 349-356 


\section{The Maritime Century}

To understand why I make that claim, we need to look back some five hundred years, when the faint outlines of today's global maritime order began to emerge in two central but essentially competing ideas that have existed in a state of tension since the English and the Dutch first went to war over them:

- The first idea is mare liberum - the concept that the seas cannot be made sovereign and hence are free for all to use, and

- $\quad$ The second is mare clausum - the idea that the sea can be made sovereign to the limits of effective state control.

Today's maritime order is based on a delicate legal and political balance of these two ideas, a balance achieved in the closing decades of the twentieth century, not in bloodshed, but rather through an unprecedented degree of international consultation that led to the United Nations Convention on the Law of the Sea, or UNCLOS. ${ }^{2}$

UNCLOS was forged out of a compelling need to create a new balance between the economic and national interests of the world's coastal states, many of which in the developing world had only recently emerged from the shadow of colonialism, with the traditional defence and security interests of the great maritime powers. That makes UNCLOS arguably history's crowning legal achievement, but what made it possible is the fact that the maritime powers and the coastal states risked suffering equally from an unregulated, disputed and unstable maritime order. Nonetheless, it is by no means assured that the remarkable consensus embodied in UNCLOS will withstand the tremendous changes this century is likely to witness. And to understand why, we need to look no further than Canada's high north.

\section{A Parable of Change}

We are likely to see more change in the Arctic in the coming three decades than has occurred since Europeans first arrived in Greenland - a result of the convergence of mutual interactions between climate change, growing global energy demand and the existential imperatives of energy security. For this reason, the Arctic serves as a parable of change for this maritime century.

The Arctic is being propelled towards the centre of global affairs, as the five Arctic coastal states - Canada, Denmark, Norway, Russia and the United States establish their claims to the vast energy and mineral reserves that already have been discovered, or are believed to lie, in the Arctic Basin and its periphery. Climate change and improvements in extraction technologies are likely to make these resources commercially exploitable perhaps decades sooner than was thought possible only a few years ago, bringing with them a host of economic opportunities, but also accelerating social change in northern societies as traditional lifestyles and economies are

2 For a full discussion of the Convention and its development, with links to the original documents, see: http://en.wikipedia.org/wiki/United_Nations_Convention_on_the_Law_of_the_Sea (accessed 1 November 2010). 
progressively altered. New and unprecedented levels of human activity in the high north will also pose risks to the environment even as global warming continues to alter Arctic ecosystems.

Environmental and social pressures on this region will mount, as will competition for access and control of strategic resources. They will do so because the stakes are potentially enormous, and not only for the five Arctic coastal states, but also for other Arctic nations, including Finland, Iceland, Sweden, and the region's indigenous peoples, as well as other non-Arctic actors, many of whom have already declared their interests. Historically, pressures of this magnitude would invariably lead to a significant rise in tensions, and indeed the future could unfold in this manner in many parts of the world.

That stated, the shared interests of the five Arctic coastal states, their stability, and the Law of the Sea offer here, as perhaps nowhere else, the opportunity for peaceful resolution of maritime disputes. This is certainly what Canada aspires to, and the agreement recently reached by Russia and Norway on the Svalbard Shelf ${ }^{3}$ would suggest that the Arctic may serve as a model for other regions of the world where ocean politics are potentially far more contentious.

Amidst the uncertainty and volatility of today's world, one thing is clear: ocean politics will continue to intensify in the coming decades, making for a 'global maritime commons' of great strategic complexity and growing strategic competition, with a latent, but increasing potential for conflict among great states.

Nowhere is this more apparent than in the Indo-Pacific, where ocean politics already occupy centre-stage. China - the region's most rapidly growing maritime power - acknowledged a fundamental strategic reality when it recently stated that its principal vulnerabilities and threats came from the sea. ${ }^{4}$ This is a remarkable shift for a state which has focused for millennia on protecting its frontiers from threats originating inland. But it is a shift that also was inevitable as China assumed a more prominent place in a global system that depends on maritime commerce and the fundamental openness of the 'great commons', as Alfred T. Mahan once described them. It is the echo of a powerful geopolitical idea, expressed in the following words written in the early-sixteenth century and now pertinent to all states, that "[w]hoever is Lord of Malacca has his hand on the throat of Venice."

What is very clear today is that the world's oceans no longer serve to shield Canada from far-distant events. Rather, they connect us through a vast and intricate web of relationships - political, economic, financial and social - that has made us neighbours

3 "Russia and Norway Settle Arctic Boundary Dispute," New York Times, 15 September 2010, on-line at: http://www.nytimes.com/2010/09/16/world/europe/16russia.html (accessed 1 November 2010).

4 U.S.-China Economic and Security Review Commission, Annual Report 2009 (Washington, DC), 133, on-line at: www.uscc.gov/annual_report/2009/chapter2_section_2.pdf (accessed 2 November 2010).

5 Tomé Pires, Suma Oriental of Tome Pires: An Account of the East, from the Red Sea to China, Written in Malacca and India, 1512-1515 (New Delhi: Asian Educational Services, 2005 [reprint]), lxxv. 
with all the world's peoples. Our prosperity and security are thoroughly enmeshed in a global system that transcends all boundaries. It is a system that depends to varying degrees on regulated air, space and cyber commons for its functioning, but it would not function at all without a regulated ocean commons. Defending that system is not a matter of choice for Canada; it is essential to our way of life.

In fact, I would maintain that among the most essential public goods of this globalised era is a regulated ocean commons. By this I mean an ocean regime in which the seas are open for all to use freely and lawfully, regulated against the increasingly troubling range of illegal and criminal activities that are occurring on them, and defended against those who would threaten the pillars upon which good order at sea depends.

\section{The Navy's Strategic Concept}

The Canadian navy's strategic concept is simply this: to defend the global system at home and abroad, both at sea and from the sea. But a strategic concept must not only describe the 'why', or our strategic 'ends'. It must also describe the 'ways' and 'means' that bring it to effect: in essence, why a navy, to what purpose it will be geared and how we will bring it to fruition.

We will defend the global system by:

- Protecting a regulated ocean commons at home and abroad,

- Promoting 'good' around the world in the national interest,

- Preventing conflict wherever possible, and lastly

- Prevailing in combat when necessary.

Let me say a little about each of these four strategic 'ways' in turn, beginning with the need to protect a regulated commons at home. Few states have benefited as much from the Law of the Sea treaty as Canada. It has endowed us with an immense ocean estate, one that extends beyond our shores to encompass the riches of more than 3.5 percent of the planet's entire surface. This represents a priceless inheritance for generations to come, with inalienable sovereign authority over nearly one-half of this massive oceanic reach, but as well with special duties of care and custody for the resources and ecosystems of the remainder. Anything that challenges or threatens to challenge the geo-political balance embodied in UNCLOS therefore touches deeply on Canada's national interest.

The responsibility to regulate the ocean commons in our own home waters must be taken by Canada alone, even if we were to develop closer arrangements with our American neighbours to defend the three ocean approaches to North America. But this task is not exclusively the preserve of the navy. It requires a comprehensive, "whole of government' approach in which Canada is considered a world leader.

Defending the global system may begin at home but it must also be defended abroad, and this clearly is the work of navies. Only navies can ensure the safety of waters that are likely to become increasingly contested by a range of actors. These actors may be purely criminal and opportunistic, as we are seeing today off Somalia or the Gulf of Guinea, or they may be armed maritime groups whose political purpose and access to 
increasingly sophisticated weapons can be used to hold even an advanced navy at risk, as Hezbollah demonstrated in its successful missile strike on an Israeli corvette in 2006.

But even the largest of navies cannot be everywhere. This is why the leaders of many like-minded navies speak of the need for a maritime strategy that seeks to enlist all coastal states and maritime powers to regulate the ocean commons cooperatively, to the extent permitted by their capacities. We need to build a meaningful capacity within the Canadian Forces, including the navy, to help build the capacity of others. Not only must we defend the global system at sea, we must also defend the conditions that permit the global system to flourish, by being able to operate as part of a joint force 'from the sea'. There's a reason we are seeing maritime - and indeed military - diplomacy being recalibrated toward entire populations through the elevation of humanitarian assistance and disaster relief as core military missions among our closest allies. Promoting good is not just the right thing to do - it is in the national interest because of the crucial roles populations will play in the collective prospects for globalization.

This is not to say that traditional maritime diplomacy will no longer be important. In fact, it is probably more important now in this globalism era than 'gunboat diplomacy' ever was. At the strategic level, forward-deployed maritime forces help to prevent and contain conflict. They provide Canada with insight and influence, promote trust and confidence among our friends, and give pause to our potential adversaries.

At the operational level, forward-deployed maritime forces provide options to government. They provide the ability to respond quickly to unfolding events and a range of choices that can be carefully calibrated to the situation, including creating the time for diplomacy to work, and declaring intent without irreversible entanglement. Nothing says commitment like 'boots on the ground', whether they be worn by sailors, aviators or soldiers. However, when the decision is taken to act, maritime forces permit governments the choice of when and where to commit a force.

Defending the global system 'from the sea' doesn't require the kind of high-end capabilities that are associated with modern amphibious warfare, which tend in the public imagination to evoke images of the momentous landings on Normandy, Iwo Jima or Inchon. These kinds of 'high-end' capabilities are beyond Canada's aspirations. What is within our national ambition, as declared by the current government, is the capacity, in relatively permissive environments, to deliver a force ashore and to sustain it there indefinitely without reliance on shore-based infrastructure. As the response to the devastating earthquake in Haiti so recently demonstrated, there is a whole range of operations where such a capacity would permit Canada to project its power and influence to defend the global system from the sea. ${ }^{6}$

The world's littoral regions - that relatively narrow zone along the coastline where the vast majority of the world's populations live - will not always be permissive as we saw in Haiti. The effects of massive change along every human axis are increasingly

6 Virginia Beaton, "Naval Task ForceGroup Assists in Haiti Relief Effort," on-line at: http://www.navy.forces.gc.ca/cms/3/3-a_eng.asp?category=8\&id=782 (accessed 1 November 2010). 
being concentrated in the littorals, and they are bringing new threats and challenges seawards. Accordingly, let me elaborate upon what that future war at sea in the littorals may look like, as this will drive the strategic 'means' that we must fashion in the coming decades.

\section{Future Maritime Operations}

While the underlying nature of conflict will not change, the means of warfare will continue to evolve. Ashore, in places such as Afghanistan, we have seen the emergence of the so-called 'hybrid adversary': an adversary who has learned to blend all forms of violence to his ends, using superior knowledge of local terrain - physical, social and cultural - to fight from a position of relative advantage.

While such adversaries have not yet mastered the maritime domain to the extent required to challenge advanced navies, the trends are clearly evident in their recent successes. $^{7}$ Some of these threats, from transnational criminal gangs to more highly organised maritime irregulars, insurgents, and state proxies, are already latent in the operations we are conducting around the world. Moreover, certain states already have demonstrated the capacity to orchestrate maritime non-state actors against a coalition, as a means of leveraging their own high-end conventional and asymmetric capabilities.

Accordingly, we must be prepared now and in the future to be confronted at sea by a wider range of potential threats and challenges than we have ever dealt with before, against a backdrop of widespread disorder and criminality ashore. Tomorrow's hybrid adversaries are likely to avoid engaging us to our strengths, working all levers to deny us access indirectly through political action. In more openly hostile situations, adversaries may seek to employ area denial weapons such as mines. Some adversaries will attempt to employ more sophisticated area denial capabilities that target key coalition nodes in physical or cyberspace, employing high-end conventional or asymmetric capabilities. In open hostilities, engagements may well be fought in close proximity with an adversary's non-conventional, irregular and asymmetric forces, or fought at longer range when highend capabilities are brought to bear. A sophisticated adversary will likely attempt both simultaneously, in an attempt to overwhelm our battle networks. Engagements may develop suddenly, at a perceived weak point, and be conducted with intensity along multiple lines of attack, followed by rapid disengagement into the littoral background.

War at sea will require fully integrated offensive and defensive actions across all physical dimensions in the maritime domain - from the seabed to space - as well as full use of the electromagnetic and informational environments. There is little doubt that it will require a complete integration of maritime coalition forces at the technical, tactical and doctrinal levels.

Moreover, it is far from certain that the West will continue to enjoy its current technological and materiel advantages, and Canada is unlikely ever to enjoy the

7 Examples include: the suicide attack of the USS Cole (2000); the attack by Hezbollah on the Israeli Navy corvette Hanit using a variant of the C802 Silkworm anti-ship missile (2006); and the terrorist attacks launched from the sea against Mumbai (2008). 
advantage of numbers. This means that we must become far more 'agile and adaptable' as a fighting force. Indeed, I would contend that agility and adaptability - from the tactical level to the strategic - must become a defining hallmark not just of the future navy but also of the Canadian Forces of the future.

Let us examine what this may mean for the navy institution as a whole in the coming decades.

\section{Tomorrow's Navy Institution}

In terms of organization, the demands of future operations against hybrid threats and challenges are likely to drive the Canadian Forces to seek a much deeper level of integration across the whole of government, as we seek to employ and leverage military power more holistically with all elements of national influence and power. In this regard, standing whole of government organizations, such as Canada's two Maritime Security Operations Centres, may already be pointing the way towards the kinds of new organizations that will be needed in the future at the strategic, operational and tactical levels.

Moreover, we already are moving towards a broader understanding of the navy's constabulary, diplomatic and military functions in this globalised era, as witnessed by the elevation of humanitarian assistance and disaster relief as core military missions by both Canada and our close allies. In this vein, operations in the littorals, especially those conducted 'from the sea', will centre increasingly on influencing populations and establishing the conditions to achieve strategic advantage in what some have called 'the battle of the narrative'. This will not be achieved through isolated acts of goodwill, nor can it be left to the moment of armed intervention by the international community. It will require a long-term approach to maritime diplomacy and a thorough understanding of the cultural, religious, political and historical context of future operations.

Canada has long sought collective approaches to security and will continue to do so. Alliances certainly will remain central, but new strategic relationships and partnerships also will offer opportunities for cooperation, burden sharing, mutual leveraging and influence, confidence building, situational awareness, and strategic insight. The navy has already cultivated a number of strategic relationships with navies of similar strategic culture and outlook, but other relationships will be needed as well in regions of strategic interest to Canada.

Turning to platforms, adaptability and agility at the level of ship and system design - of everything from steel to software - will be essential if we are to succeed in matching the navy's cycle of technological adaptation to the highly dynamic cycle of adaptation that appears to be a key characteristic of hybrid warfare. Recent advances in warship design have made it possible to build much more flexibility into warships, including: 'modularity' of major weapons and sensors; flexible deck arrangements; and standards-based 'open architectures' that will enhance the navy's adaptability to meet emerging and evolutionary requirements.

Adaptability and agility in design will also permit naval force planners to 
investigate new warship crewing models, to examine potential new approaches to the overall fleet 'quantity versus quality' balance, and new potential trade-offs in the navy's major procurements and acquisitions. Technological agility, moreover, will be necessary to address urgent and unforeseen requirements, including the ongoing and rapid development and testing of solutions, the development of associated tactics in distributed synthetic environments, and the real-time implementation of solutions in a deployed force. This will also require us to continue to invest significantly in tactical and doctrinal development, as we seek to tighten the 'feedback loop' between lessons learned and the implementation of integrated solutions to operational deficiencies. Finally, technological agility will be essential if we are to address the emergence of potentially highly disruptive weapons and technologies in the coming decades, in a world where wealth and power are no longer concentrated among our closest allies and defence partners.

The recent Canadian Forces operation in Haiti illustrated one of our clear strengths: our people. They are the key to our future success, and so they must remain a key area of investment. This is not merely a matter of ensuring that the Canadian Forces adopt policies that make sense for a Canadian population that is evolving dramatically in terms of workplace expectations and demographics. This is about making sure that our people have the skills and competencies that hybrid warfare will demand of them.

\section{Concluding Remarks}

The government entrusts to the Canadian Forces responsibility for defending Canada, defending North America, and contributing to international peace and security. The navy has vital roles to play in each of these enduring pillars of defence policy. Defending the global system is fundamental to all three, as is the capacity to defend from the sea the conditions that permit the global system to prosper. This is our unique contribution towards Canada's prosperity, security and national interests, and has been since the navy's creation in 1910. This is what makes Canada's globally deployable, sea control navy of enduring relevance in this maritime century. 